\title{
Tantangan primordialisme dalam upaya membangun budaya politik nasional
}

\author{
Asep Nurjamana,1 \\ a Universitas Muhammadiyah Malang, Jalan Raya Tlogomas 246, Malang, 65144, Indonesia \\ ${ }^{1}$ asepip@umm.ac.id
}

* Corresponding Author

\section{INFO ARTIKEL \\ Sejarah Artikel:}

Diterima: 3 September 2021

Direvisi: 17 September 2021

Disetujui: 28 September 2021

Tersedia Daring: 31 Oktober 2021

Kata Kunci:

Demokrasi

Indonesia

Konflik

Negara-Bangsa

Primordialisme

\begin{abstract}
ABSTRAK
Persatuan dan kesatuan bangsa sangat penting dalam sebuah negara bangsa (nation state). Indonesia dihadapkan pada persoalan heterogenitas suku, bahasa, ras, agama, dan kedaerahan yang menjadi tantangan dalam membangunan budaya politik nasional. Oleh karena itu tujuan artikle ini adalah untuk mengkaji ikatan primordial dalam proses national and character building. Penelitian ini menggunakan pendekatan kualitatif dengan metode studi literatur. Sementara teknis analisanya menggunakan analisis isi. Kebutuhan data diambil dari berbagai sumber, baik buku, jurnal, maupun dokumen cetak dan digital. Temuan penelitian menunjukan bahwa (1) Primordialisme menjadi unsur yang paling penting dalam kenakaragaman bangsa dan berperan dalam menumbuhkan patriotisme, namun menjadi tantangan ketika membangun budaya nasional, (2) negara melakukan berbagai upaya dalam mempersatukan keragaman memalui berbagai kebijakan seperti monitisasi ideologi yang cenderung mengarah ke totaliter. Hal tersebut berimplikasi pada marginalisasi dan eliminasi yang menghambat kebebasan yang penting dalam membangun kreativitas dan inovasi dalam negara demokrasi.

\section{ABSTRACT}

Unity and diversity is the most urgent thing in a nation-state (nationstate). Indonesia is faced with the problem of ethnic, linguistic, racial, religious, and regional heterogeneity which is a challenge in building a national political culture. Therefore, the purpose of this paper is to examine primordial bonds in the process of national and character building. This study used a qualitative approach with a systematic literature method. While the technical analysis used content analysis. Data needs were taken from various sources, books, journals, and documents, both printed and digital. The research findings show that: (1) Primordialism is the most important element in the diversity of the nation and play a role in fostering patriotism, but it becomes a challenge when building a national culture. (2) The state makes various efforts to unite diversity through various policies such as ideology uniformity which tends to lead to totalitarian. This has implications for marginalization and elimination that hinder freedom which is important in building creativity and innovation in a democratic country.
\end{abstract}

Keywords:

Primordialism

Conflict

Nation-State

Democracy

Indonesia

(C) 2021, Nurjaman

This is an open access article under CC-BY-SA license (c) (i) (O)

How to Cite: Nurjaman, A. (2021). Tantangan primordialisme dalam upaya membangun budaya politik nasional. Satwika : Kajian Ilmu Budaya dan Perubahan Sosial, 5(2), 370-383. https://doi.org/10.22219/satwika.v5i2.17990 


\section{Pendahuluan}

Perkembangan paling penting di era saat ini, tepatnya, adalah memudarnya negara bangsa (Alkatiri, 2018; Sai, 2008; Tanzi, 1998), yaitu: ketidakmampuan untuk menahan kekuatan global yang berlawanan, dan hilangnya pengaruhnya yang dahsyat atas keberadaan manusia. Otoritas politik nasional sedang menurun dan rasanya seperti berada dalam akhir dunia (Tanzi, 1998). Di sisi lain negara-negara baru merdeka rentan terhadap perpecahan yang serius yang ditimbulkan oleh ikatan-ikatan primordial dalam sebuah negara (Fawaid, Zamroni, \& Baharun, 2019; Gauthier, 2011; Hidayat, 2019; Resminingayu, 2020; Rizqi, 2020). Ikatan Primordial menurut Geertz (Berger, 2006; Fionna, 2016; Hadiz, 2017; Miedema, 2010; Weiss, 2010), Ikatan primordial adalah ikatan yang berasal dari unsur-unsur bawaan, atau lebih persis lagi unsur-unsur bawaan yang diandalkam dari kehidupan sosial, hubungan langsung dan terutama hubungan kekerabatan. Lebih jauh, keadaan bawaan yang berasal dari keadaan seperti komunitas religiustertentu, bertutur dengan sebuah bahasa tertentu, atau bahkan sebuah dialek bahasa tertentu, dan mengikuti praktek-prakter sosial tertentu. Indonesia merupakan salah satu negara yang memepunyai keanekaragaman budaya dan entik yang sangat besar.

Dalam kenyataan keseharian, ikatan primordial yang bersumber dari kesesuaian darah, turunan, adat kebiasaan, agama, memiliki sebuah kekuatan yang dapat melakukan paksaan, dan kadang lebih kuat dari kesesuaian secara nasional. Kekuatan umum dari ikatan-ikatan primordial semacam itu berbeda dari orang ke orang, dari masyarakat ke masyarakat. Oleh karena itu Geertz (1965) mengemukakan bahwa "Negara baru mengalami kesukaran membangun suatu sistem politik yang baik, antara lain masih terdapatnya "primordial attachment" yang dalam, yaitu suatu rasa keterikatan pada golongan tertentu karena pengaruh adat istiadat, bahasa, ras, daerah, hubungan darah, atau agama. Rasa keterikatan semacam ini sering disebut sebagai pengaruh "sub national culturevallue" atau pengaruh kebudayaan politik subnasional (Partnership, 2008).

Kristalisasi dari konflik langsung antara sentimen-sentimen primordial dan sentimen-sentimen sipil ini menurut Geertz (1965) yaitu keengganan untuk termasuk dalam salah satu kelompok lain. Inilah yang memunculkan masalah seperti sukuisme, daerahisme, komunalisme, dan lain sebagainya. Di dalam tingkah laku politik sehari-hari, seringkali pengaruh kebudayaan politik subnasional anggota masyarakat sangat menonjol peranannya sehingga mengakibatkan terganggunya pengembangan kebudayaan politik yang bersifat nasional. Dengan kata lain, proses integrasi atau pembinaan bangsa sering tidak berjalan lancar atau mengalami kemunduran. Kenyataan ini disebabakan masih adanya rasa kedaerahan atau kesukuan sebagai mana tercermin dalam pola-pola kepartaian (Leib \& Garretson, 2003), pengikut dan kepemimpinan yang masih dipengaruhi ciri-ciri kebudayaan politik subnasional. Bahkan di era akhirakhir ini sejumlah penelitian menunjukkan tren peningkatan primordialisme berbasis identitas agama, etnis, dan kelas melalui media sosial (Hidayat, 2019). Selain itu juga masih berlangsungnya proses produksi dan reproduksi informasi palsu di media sosial yang berfokus pada kepentingan politik tertentu (Saddam et. al., 2020).

Penyebab konflik dalam masyarakat multietnis dan multi-agama bukanlah keragaman itu sendiri, namun sikap seseorang terhadap keragaman. Dengan demikian perlu ada sikap yang inklusif dan adil dalam dalam berbagai hal, seperti berbagi kekuatan politik dan pembangunan ekonomi dengan daerah dan komunitas minoritas, termasuk mengakui identitas budaya minoritas. Dalam membangun negara-bangsa perlu mengedepankan Bangsa dalam bingkai wilayah Indonesia. 
Oleh karena itu upaya untuk melakukan desentralisasi kekuasaan dan sumber daya menjadi bagian yang tidak terpisahkan dalam rangka membangun Indonesia.

Terkait dengan semangat nasionalisme sempit, Hooghe \& Marks (2017) mengutip pernyataan Lipset dan Rokkan (1967), menyampaikan bahwa "kita waspada terhadap perubahan sosial yang merusak konflik kelas, tetapi mereka tidak tahu bahwa wadah-negara nasional-akan diubah dalam dekade sekitar pergantian abad ke-21". Identitas teritorial sebagai motif konflik dianggap sebagai sesuatu dari masa lalu. Nasionalisme sempit yang berbasis etnis di dalam negara dianggap sebagai sisasisa pemikiran lama yang mengganggu pembangunan bangsa.

Lepas dari hal tersebut, jiwa patriotrisme telah terbukti dapat menjadi sumber berharga dalam melawan penjajah. Patriotisme yang berbasis primordial ini perlu disesuaikan dengan sikap nasionalisme yang berbingkai wilayah Indonesia. Dalam kaitannya dengan ketahanan negara Asmoro et al., (2021) mengungkapkan bahwa pemahaman tentang patriotisme yang komprehensif dan nasionalisme juga tidak dapat dilepaskan pada upaya pengelolaan sumber daya alam, sumber daya buatan dan infrastruktur untuk mendukung pertahanan negara. Nasionalisme dapat diartikan sebagai rasa cinta terhadap tanah air dari seseorang, dan kesediaan untuk mengorbankan diri untuk mempertahankannya dalam payung negara bangsa (nation-state).

Lebih jauh, terkait proses pembangunan politik bangsa ada dua pendekatan yang saling berhadapan yaitu pasca-modernisme dengan modernisme. Pasca-modernisme menganut doktrin realis, sementara modernisme dicirikan oleh penerimaan bahwa hukum dan kebenaran umum dapat dicapai melalui akal, ilmu pengetahuan, dan teknologi, dan dengan demikian kemajuan dimungkinkan Pasca-modernisme dalam banyak hal menentang ide-ide semacam itu. Postmodernisme hanya menerima relatif sebagai kategori yang bermakna, melarang kategori kebenaran dari wacana intelektual, dan, menolak gagasan kemajuan demi kebenaran lokal, unik, pribadi, dan kontekstual. Dari perspektif itu, munculnya konflik dalam masyarakat multi-etnis di negara-negara pasca-kolonial memperkuat ketidakcukupan model negara-bangsa modern dan pembangunan bangsa sebagai sarana untuk mencapai kesetaraan dan keadilan sosial (Alkatiri, 2018).

Proses pembangunan politik kebanyakan di negara sedang berkembang, termasuk Indonesia, mengandung beberapa persamaan dan perbedaan. Salah satu persamaannya adalah pergulatan dalam mencari mekanisme politik yang tepat dan dapat diandalkan. Dalam proses pencarian itu sering ditemui berbagai macam kesulitan yang kadang-kadang mengancam kelangsungan hidup mereka sebagai suatu negara yang merdeka dan berdaulat. Kesulitan-kesulitan itu mungkin bersumber dari luar, dari dalam, atau kombinasi keduanya. Meskipun demikian, ancaman yang paling berat bagi pengalaman suatu masyarakat berasal dari dalam diri yang biasanya juga mengundang ancaman dari luar. Sejalan dengan itu, suatu bangsa yang berhasil mengatasi krisis atau kesulitan yang terkandung di dalam mempunyai kemampuan yang lebih besar untuk bisa menghalau segala bentuk ancaman dari luarideologi, kebudayaan, ekonomi, politik, ataupun militer.

Ada beberapa negara yang mengalami proses pembangunan ekonomi yang menggembirakan tanpa diikuti oleh proses pembangunan politik yang serasi. Untuk beberapa lama proses perkembangan ekonomi dapat berjalan sendiri tanpa adanya gangguan yang mengkawatirkan. Akan tetapi, setelah sekian lama ternyata perkembangan ekonomi yang sudah sedemikian baik tidak lekas diikuti oleh perkembangan politik yang sejajar, akhirnya terjadilah krisis politik sebagai akibat langsung dari kesenjangan perkembangan antara keduanya. Krisis-krisis politik ini sedemikian hebatnya sehingga mengganggu jalannya proses perkembangan ekonomi 
yang sudah berjalan. Indonesia, dalam setengah abad ini, mempunyai masalah yang unik. Keunikan ini terlihat dari sisi budaya, bahasa, agama, dan geografi.

Kenyataan ini juga yang telah berpengaruh besar terhadap proses pembangunan politik selama ini sebagaimana yang dialami semasa pemerintahan Orde Lama dan Orde Baru. Dari semua upaya yang dilakukan oleh penguasa dalam rangka memperkuat ke Indonesiaan, rekayasa sosial politik makin mendorong pemerintah untuk mengefektifkan kebijakan stabilitas politik. Berbagai litratur tersebut di atas menunjukan bahwa primordialisme merupakan satu kekuatan karena melahirkan jiwa patriotisme, namun patriotisme yang tidak dibumbui dengan kesadaran berbangsa dan bernegara akan mengganggu kesatuan dan persatuan bangsa. Tulisan ini bertujuan untuk mengkaji identitas politik nasional yang heterogen dan upaya pemerintah dalam menangani pluralisme berbasis primordial di Indonesia.

Kajian ini berkontribusi pada pengembangan ilmu budaya, khususnya budaya kewarganegaraan. Secara praktis, hasil kajian ini mendorong kesadaran dan wawasan kebangsaan terkait dengan heterogenitas bangsa Indonesia agar bisa saling menghargai dan membangun toleransi agar persatuan dan kesatuan bangsa terpelihara dan negara Indonesia tetap utuh. Lebih jauh, kajian ini bisa menjadi inspirasi penelitian selanjutnya terkait dengan pendidikan karakter keangasaan, maupun pendidikan politik kaum muda di Indonesia.

\section{Metode}

Penelitian ini termasuk kajian studi literatur. Metode yang digunakan adalah sistematik literature review. Studi literatur merupakan hal penting dalam penelitian ilmiah. Pada dasarnya, kemajuan pengetahuan harus dibangun di atas pekerjaan yang sudah ada sebelumnya (Xiao \& Watson, 2019). Sebagai pertanyaan ilmiah, tinjauan pustaka harus valid, dapat diandalkan, dan dapat diulang.

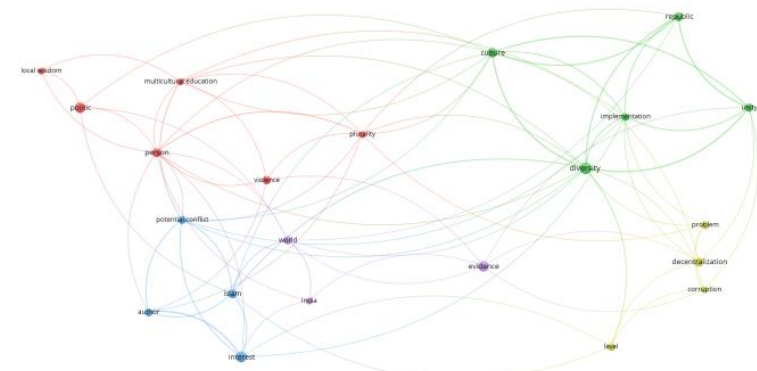

Gambar 1. Peta penelitian (Sumber: hasil olah data penulis berbasis VosViewer)

Adapun tahap penelitian diawali dengan tracing literatur dengan meggunakan Publish or Persih dan dilanjutkan dengan analis VosViewer. Metode seleksi didasarkan pada waktu terbit, kata kunci, basis data, dan memiliki kesamaan kata. Hasil tracing literatur yang relevan melalui publish or perish dibatasi sejumlah 200 literatur dengan judul primordialisme dan pembangunan politik nasional. Survry data ditelusuri pada basis data Google Cendikia. Dalam penelusuran dilakukan pembatasan tanggal tahun publikasi, yaitu pada 20162021 (artikle yang diterbitkan dalam lima tahun terakhir). Setelah didapatkan sejumlah literatur lantas dianalsisis menggunakan VosViewer untuk mencari kesamaan kalimat dengan pembatasan empat kata yang sama dari judul dan abstrak (lihat gambar 1). Ada 34 artikel yang mempunya kesamaan kata secara acak dalam jurnal hasil pencarian dengan kata kunci "primordialisme dan pembangunan Politik".

\section{Hasil dan Pembahasan}

\subsection{Primordialisme dan Konflik di Indonesia}

Primordialisme sebagai pola pikir memiliki dampak positif dan negatif. Dampak positif dari primordialisme bermanfaat untuk memperkuat loyalitas seseorang terhadap suku bangsanya dan juga untuk meningkatkan moral, nasionalisme dan patriotisme seseorang. Primordialisme juga dapat dijadikan pedoman dalam kehidupan bermasyarakat, dalam menghadapi berbagai bentuk perubahan sosial. Namun, sikap primordialisme juga 
banyak memberikan dampak negatif bagi masyarakat multikultural karena memicu perpecahan yang tentunya merugikan individu atau kelompok etnis lain. Sikap ini sangat menghambat proses harmonisasi masyarakat dan proses globalisasi dalam konteks kehidupan internasional (Rizqi, 2020). Kondisi di Indonesia juga menunjukan adanya ekses negatif dari keanekaragamaan ini dengan banyaknya konflik yang terjadi.

Salah satu konflik berbasis primodial di Indonesia banyak melibatkan penduduk etnis Tionghoa dengan pribumi. Purdey (Resminingayu, 2020) berpendapat bahwa orang menyalahkan pedagang terutama orang Indonesia Tionghoa karena kondisi ekonomi yang turun. Orang Indonesia Tionghoa kemudian menjadi korban perampokan, pemerkosaan, dan penyerangan akibat percepatan suasana anti Tionghoa di seluruh Indonesia. Kerusuhan Mei 1998 merupakan klimaks dari gerakan anti-Cina yang menyebabkan Soeharto menyerahkan kekuasaannya. Namun, setelah jatuhnya sistem oligarki Soeharto, situasi orang Indonesia Tionghoa semakin membaik karena Gus Dur, sebagai Presiden Indonesia selanjutnya memberikan lebih banyak kebebasan kepada orang Indonesia Tionghoa dengan membatalkan Keppres No.14 tahun 1967. Sejak itu, orang Tionghoa dapat mengekspresikan identitas dan budaya mereka secara bebas, disusul dengan pengakuan Konghucu sebagai agama keenam di Indonesia. Permintaan untuk mengadakan Imlek (tahun baru Imlek) sebagai perayaan Khonghucu juga dikabulkan.

Di samping konflik yang bersumber dari perbedaan etnis, sumber konflik lain juga berasal dari persoalan kedaerahan. Bentuk konflik yang terjadi bisa upaya memisahkan diri (separatisme), atau pengusiran etnis pendatang.

Pendapat lain datang dari Alkatiri (2018), yang menyebutkan bahwa konflik di Indonesia berasal dari nasionalisme dan ideologi politik-ekonomi daripada perbedaan budaya. Dengan menyoroti dua isu relevansi global dijelaskan sebaga berikut: Pertama, masalah koeksistensi yang melekat yang muncul dari warisan tradisi misionaris Kristen yang menganjurkan pemisahan negara dan agama di tanah jajahan, padahal Islam adalah agama politik dan hukum. Kedua, konsep al-din hampir tidak sesuai dengan konsep agama Barat. Selanjutnya Alkatiri (2018), menyatakan bahwa dalam globalisasi kontemporer, negara bangsa modern dan nasionalisme semakin kontras dengan sifat 'kosmik' agama, yang mengklaim kesetiaan melampaui perbedaan ras dan kebangsaan. Namun menurut penulis, sisi baiknya, studi kasus "komunitas intensional" Muslim menawarkan solusi pragmatis di mana implementasi yurisprudensi Islam sebagai respons terhadap masalah ekologis oleh kelompok Muslim individu dapat dilakukan dalam batasan negara bangsa.

\subsection{Upaya Membangun Budaya Politik Nasional}

Indonesia mengalami kesukaran membangun satu sistem politik yang baik, dikarenakan terdapatnya "primordial attachment" yaitu suatu rasa keterikatan pada golongan tertentu karena pengaruh adat istiadat, bahasa, ras, daerah, hubungan darah atau keagamaan. Akibat dari unsur primordial ini (primordial attachment) proses unifikasi bangsa sangat sulit dilakukan. Sentimen-sentimen yang didasarkan pada unsur primordial lebih mengedepan dibanding dengan kepentingan bangsa dan negara yang lebih luas.

Pembangunan budaya nasional Indonesia merupakan proyek jangka panjang yang harus diselesaikan dari generasi ke generasi. Persoalan besar dalam proses penyatuan bangsa ini terletak pada kerelaan menerima realitas perbedaan dan kesediaan untuk hidup berdampingan secara damai. Banyak benang kusut konflik di Indonesia yang harus diselesaikan. Secara umum konflik di Indonesia bisa di bagi ke dalam konflik horizontal dan konflik vertikal. Konflik horizontal biasanya bersumber dari perbedaan yang melekat antar-sesama 
bangsa Indonesia. Kasus yang sering muncul adalah intoleransi atas perbedaan perbedaan yang bersumber dari keragaman dalam kehidupan sosial maupun dalam pelaksanaan pemilu (Wahidin, Muhyidin, Iswahyuni, \& Ilmar, 2020).

Berbicara secara vertikal lebih banyak terkait dengan hubungan Islam dan negara. Telah dipahami bahwa pembangunan politik Indonesia, tidak bisa dilepaskan dari unsur Islam, Jawa dan negara. Dari satu rezim ke rezim lain menunjukan simbol otoritas dengan tujuan politik yang berbeda dalam menggunakan arsitektur, hal ini menurut Fawaid et al., (2019) menimbulkan pertanyaan penting tentang bagaimana negara-bangsa harus direpresentasikan dalam bentuk arsitektur masjid. Penulis menyebutkan bahwa pilihan antara Masjid Istiqlal, Demak, atau Daan Mogot yang menunjukan adanya potensi konflik, sebagai contoh bagaimana mereka menegosiasikan budaya keagamaan mereka dengan gagasan negara-bangsa sekuler dan bagaimana Istiqlal, Demak, dan Dan Moogot menjadi bagian dari pandangan dunia Islam dan Jawa? Itu semua bisa jadi petunjuk akan potensi konflik yang ada di Indonesia.

Potret konflik dan kebragamaan Indonesia jika diangkat ke ranah politik dapat memperlihatkan adanya keberagaman dalam partai politik yang telah mewarnai sejarah panjang demokrasi Indonesia dari mulai pemilu 1955 sampai saat ini. Perjalanan perkembangan sejarah politik Indonesia menunjukkan pengalamanpengalaman yang pahit dengan pembagian kekuasaan yang ruwet sebagaimana tercermin di dalam banyak partai (Darby, Li,

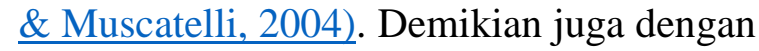
pemusatan kekuasaan di satu orang atau segelintir orang.

Dalam politik, partai-partai mempunyai akarnya sendiri sebagai cerminan heterogenitas bangsa telah mewarnai kehidupan politik Indonesia seperti PNI, Masyumi, NU, PKI, PSII, Parkindo, dan lain sebagainya. Akibat kuatnya pada salah satu unsur primordial, kadang kala partai partai yang ada sulit sekali untuk dapat dipertemukan yang pada akhirnya konflik terus berkembang tanpa ada penyelesaian. Konflik partai yang terutama didasarkan pada primordialisme dan ideologi ini semakin lama semakin meruncing. Parlemen hasil pemilu 1955 (Reimondos \& Mcdonald, 2015), telah cepat merebak dan terjebak dalam konflik yang berkepanjangan yang menyangkut penentuan dasar negara, yang satu ingin mempertahankan Pancasila dan yang kedua ingin berdasarkan Islam. Hal ini telah berakibat jatuh bangunnya kabinet yang menyebabkan pemerintahan tidak dapat menjalankan aktivitasnya. Untuk mengatasi berlarut-larutnya konflik ini atas inisiatif Presiden Sukarno dengan dukungan Angkatan Darat mengeluarkan Dekrit 5 Juli 1959 mengenai pembubaran parle men dan digantikan dengan DPR Gotong Royong.

Setelah kejatuhan Sukarno akibat peristiwa G. 30S/PKI muncul Orde Baru sebagai koreksi total pada Orde Lama. Penataan institusi-institusi kenegaraan dengan giat dila kukan untuk mendukung pemerintah seperti dibentuknya Golongan Karya yang merupakan gabungan dari golongan fungsional dengan didukung kekuatan ABRI. Setelah itu dilakukan fusi terhadap partai-partai yang dikukuhkan lewat Undang-undang No. 3 tahun 1973. Partai yang berasas kan Islam seperti NU, Parmusi, PSII, dan PERTI tergabung ke dalam PPP, sementara yang berasaskan Nasionalis Demokratis seperti PNI, Parkindo, Partai Katolik, IPKI, dan Murba tergabung ke dalam PDI. Kebijakan mengambang diatur dalam Undang-undang No. 3 setiap partai atau ormas hanya boleh punya perwakilan di tingkat ibu kota kabupaten. Selain itu harus juga mengakui Pancasila sebagai satu-satunya azas (monolitisasi) yang disebut sebagai azas tunggal Ideologi tahun 1975 yang diperbaharui oleh Undang-undang No. 3 tahun 1985 mengenai Parpol dan Organisasi Masa.

Berdasarkan hal tersebut, perencanaan pembangunan politik Indonesia menghendaki rumusan di mana di satu pihak pengaturan pemakaian dan pembagian 
kekuasaan lebih disederhanakan, sedangkan di pihak lain, penyederhanaan itu dilarang menjurus pada pemusatan kekuasaan. Dengan memperhatikan masalah tersebut maka pada masa Orde Baru munculah gagasan untuk menyederhanakan partaipartai yang ada melalui mekanisme fusi partai, yang berdasarkan Islam ke dalam "PPP", dan partai yang berasaskan nasionaldemokrasi ke dalam "Partai Demokrasi Indonesia (PDI)", serta "Golongan Karya (Golkar)", yaitu pada awal 1973 (Baswedan, 2004; Trihartono \& Patriadi, 2016; Wahidin et al., 2020). Pasca Orde baru, upaya upaya membangun politik Indonesia juga dilakukan melalui penyederhanaan sistem kepartaian dengan merubahan ambang batas parlemen dan meningkatkan syarat pendirian agar tidak terlalu banyak partai politik (Nurjaman, Suprapto, \& Masmuh, 2018).

Mengenai penyederhanaan partai ini Pemerintah mengeluaran Undang-undang No. 3 tahun 1973 tentang parta Politik dan Golkar. Sementara pasca Orde Baru diberlakukannya undang-undang politik dengan perubahan yang semakin memperketat pendirian partai politik dan merubah sistem pemilu aga lebih sederhana sistem kepartaiannya.

Setelah terjadi pergantian kepemimpinan Nasional, dari Suharto ke Habibie, proses pembangunan politik berubah arah dari sentralisme ke desentralisme. Iklim demokrasi berkembang pesat, kebebasan berpendapat merebak, partai politik bermunculan bak jamur di musim hujan. Persoalan lanjutan adalah politik nasional terlalu riuh karena terlalu banyaknya partai politik. Langkah di era demokratisasi lebih banyak dilakukan melalui penyederhanaan sistem kepartaian. Dari pemilu ke pemilu sistem kepartaian semakin kecil, dilihat dari banyaknya partai yang ada di parlemen.

\subsubsection{Masa Pemerintahan Orde Lama}

Semasa Orde Lama kancah politik diramaikan oleh maraknya partispasi rakyat dalam kehidupan berpolitik. Kenyataan ini dihembuskan oleh kebanyakan kaum intelektual yang sudah mengenyam pendidikan Barat, dan mereka pulalah yang kebanyakan menjadi arsitek pembangunan politik semasa Orde Lama. Dalam pandangan Sukarno, bangunan nasional Indonesia adalah kebangsaan yang luas yang disebutnya "nationale staat". Bangunan nasional tidak hanya bersatu karena sejarah yang sama dengan bangsa yang dijajah, tetapi juga karena keinginan untuk bersatu. Untuk membentuk "nationale staat" Indonesia, keinginan untuk bersatu dan sejarah bersama saja tidak cukup. Perlu adanya kesatuan pandangan hidup sebagai dasar kebangsaan, kesatuan geopolitik yang menunjukkan wilayah negara bangsa, kesatuan warga negara dari setiap penduduk, kesatuan pemerintahan yang menyelenggarakan pemerintahan nasional, kesatuan kebudayaan, bahasa, lambang negara, dan lagu kebangsaan sebagai identitas nasional (Musofiana \& Maerani, 2020).

Maraknya partisipasi rakyat pada saat Orde Lama dipengaru hi oleh nuansa yang mendukung yaitu suatu penerimaan terhadap adanya perbedaan pendapat dan pandangan (konflik) sebagai realitas sosial. Barangkali tulisan Sukarno yang berupa artikel tentang tiga aliran politik yaitu Nasionalis, Islam, dan Marxisme merupakan pengakuan terhadap perbedaan pendapat, pandangan, dan pikiran. Pemikiran Politik Sukarno ini jelas mengandung adanya konflik karena melalui itu ia melihat kemungkinan munculnya aspirasi-aspirasi rakyat yang sesungguhnya.

Di samping pemikiran Sukarno juga tercatat pemikiran-pemikiran yang berbobot dan berkualitas tinggi seperti dari Hatta. Ki Hadjar Dewantara, Sutan Sjahrir, Natsir, Agus Salim, Tan Malaka dan banyak lagi yang lain. Dari situ dapat dilihat bagaimana suasana konflik mem punyai sumbangan positif terhadap pengembangan intelektual lintas masyarakat. Sehingga pada saat itu Herbert Fieth mencatat adanya lima aliran dalam pemikiran politik, yaitu Nasionalisme Radikal, Tradisionalisme Jawa, Islam, 
Sosialisme Demokratis dan Komunisme (Ufen, 2006, 2008).

Pada masa demokrasi liberal yang berlangsung hingga 1958/1959, perdebatan di parlemen memang hebat, tetapi karena asik berdebat jarang sekali menghasilkan sesuatu yang diharapkan masyarakat banyak. Perti kaian yang berlarut-larut, menyebabkan seringnya kabinet atau pemerintahan berganti sehingga kebijakan sering berubah-ubah. Sistem banyak partai yang diperkirakan akan lenyap dengan Pemilu 1955 ternyata tidak bisa dihindari. Walaupun pemilihan itu menghasilkan empat partai besar (PNI, Masyumi, NU, dan PKI), tetapi tidak satupun yang menghasilkan satu partai mayoritas. Namun pemilu itu telah membuka pintu yang lebar bagi pertentangan ideologi yang tajam, sehingga memperdalam rasa saling curiga.

Sesudah pemilihan umum terbentuk kabinet yang dipim pin oleh tiga partai besar PNI, yaitu Masyumi, dan NU. Disamping itu beberapa partai kecil juga diikutsertakan, seperti PSII, Parkindo, dan Partai Katolik. Kabinet yang didukung oleh mayoritas besar di parlemen itu, 189 dari 272 suara, diharapkan akan mampu menjaga kestabilan nasional. Tetapi kenyataanya tidak begitu. Salah satu sebabnya karena Presiden Sukarno mulai mencampuri permainan politik secara aktif. Sewaktu susunan kabinet diusulkan kepadanya untuk disetujui, dia mempertunjukkan kekecewaannya karena satu partai besar lagi, PKI tidak termasuk. Sukarno menginginkan kabinet empat partai yaitu yang didukung oleh empat partai besar. Walaupun pada akhirnya ia menyetujui susunan kabinet yang diajukan, tetapi suasana kurang harmonis mulai muncul.

Kekurang-mantapan kabinet sebagian berasal pula dari kenyataan bahwa ia merupakan sebuah koalisi yang bisa digoyahkan oleh pertikaian-pertikaian yang terjadi. Memang begitu, perangai mudah berkonflik masih melekat kuat, sehingga kabinet sering mengalami kesulitan dalam mencapai konsensus terhadap masalahmasalah berat yang kebetulan pada waktu itu muncul pergolakan di daerah dan konsepsi politik Sukarno. Akhirnya kabinet Ali Sastra Amidjojo, yang terkenal kabinet Ali terpaksa jatuh, dan digantikan oleh kabinet Burhanuddin Harahap sampai Maret 1956.

Sementara suasana nasional bertambah gawat, pergola kan daerah meningkat, perdebatan tentang ideologi juga berlangsung. Latar belakang itu memberi kesempatan kepada Sukarno mempengaruhi dan mendominasi percaturan politik secara lebih leluasa yang dimulai dengan penunjukan dirinya sebagai formatur kabinet dan pada akhirnya bermuara pada Demokrasi Terpimpin.

Kabinet Ali yang kedua jatuh pada tanggal 14 Maret 1957, yang secara praktis berakhir pula demokrasi parle menter atau demokrasi liberal di Indonesia. Dengan dukungan militer, terutama angkatan darat, Sukarno membuba kan Dewan Konstituante dan pada tanggal 5 Juli 1959 dengan mendekritkan berlakunya kembali UndangUndang Dasar 1945, sampai akhirnya kekuasaan Presiden Sukarno jatuh dan digantikan oleh Jenderal Soeharto yang menandai lahirnya Orde Baru (Boangmanalu, 2009).

\subsubsection{Masa Pemerintahan Orde Baru}

Setelah Sukarno, presiden kedua, Suharto dan Orde Barunya, juga dikenal luas dengan penekanan pada "persatuan". Karena etnis Jawa yang dominan, pemerintah berusaha untuk menyeragamkan bangsa dan menciptakan budaya bersama dengan simbol dan nilai-nilai berdasarkan gaya dan nilai budaya Jawa sehingga memicu kemarahan yang pahit di pihak penduduk luar Jawa. Bagi mereka nasionalisme hanyalah Javanisasi sebagai bagian dari kebijakan hegemoni penguasa di Jakarta. Mulai tahun 1978, program indoktrinasi nasional, P4 (Pedoman Penghayatan dan Pengamalan Pancasila) dilakukan untuk menanamkan nilai-nilai Pancasila kepada semua warga negara, terutama anak sekolah dan pegawai negeri. Pancasila sebagai ekspresi nasionalisme kini digunakan sebagai 
instrumen kontrol sosial dan politik (Alkatiri, 2018).

Pemilihan umum di zaman Orde Baru untuk pertama kalinya berlangsung pada tanggal 3 Juli 1971, dan selan jutnya pemilupemilu dilakukan secara tertib dan teratur. Berbeda dengan jaman Orde Lama, yang sangat sulit untuk mendapatkan partai yang mayoritas walau terdapat partai yang mempunyai kekuatan besar seperti PNI, Masyumi, NU, dan PKI, Pemilu selama Orde Baru, satu kekuatan, Golongan Karya (Golkar), selalu keluar sebagai pemenang dengan mayoritas suara dan kursi. Dari beberapa kali pemilu selama Orde Baru ini, satu hal yang amat jelas kelihatan hasilnya ialah munculnya Golkar sebagai kekuatan politik dengan mayoritas tunggal, baik dalam jumlah suara maupun kursi yang diperolehnya. Tanpa mengurangi arti peranan dominan ABRI dalam kehidupan politik Indonesia, rangkaian pemilu yang dijalankan dalam zaman Orde Baru telah melahirkan satu kekuatan politik, yaitu Golkar, sebagai pemegang mayoritas suara di DPR. Hal ini berbeda dengan Orde Lama oleh karena itu merupakan satu realitas politik baru.

Ada satu fenomena yang menarik, yaitu diberlakukannya Undang-undang No. 3 tahun 1985 tentang partai politik dan Golongan Karya. Kenyataan ini telah membuat partai-partai Islam tersingkir dari arena perpolitikan, semua organisasi sosial politik dalam menyalurkan aspirasinya ditampung dalam satu wadah PPP. Hal ini mengakibatkan banyak organisasi kemasyarakatan yang berjuang di luar arena konstitusional. Di samping itu juga, strategi rekayasa masa mengambang yang diterapkan oleh pemerintah Orde Baru telah menyebabkan putusnya hubungan partai politik dengan masa di perdesaan. Akar-akar yang mempersatukan partai dengan masa yang secara sosiologis, $80 \%$ lebih berada di kawasan perdesaan telah terputus. Partai tidak bisa menjalankan fungsi sosialisasi dan komunikasi pada tingkat bawah. Dalam keadaan demikian partai tidak mengakar dan terasing dari masyarakat (Sobari, 2016).
Pemerintah Orde Baru, dalam hal ini terutama Presiden Suharto sebagai Kepala Eksekutif telah banyak mengambil inisiatifinisiatif dalam upaya untuk memperlancar proses pembangunan politik. Inisiatif ini terlihat dalam tingkat laku politik Presiden Soeharto yang menghendaki penyederhanaan sistem kepartaian tersebut di atas, dan penyatuan pimpinan DPR dan MPR. Sistem multi partai yang sudah kental dengan masyarakat Indonesia, karena kenyataan memang sudah dilaksanakan hampir tiga puluh tahun yang secara langsung memberi corak dan warna pada pola tingkah laku politik mereka. Sesuatu. yang sudah memola dan mengeras itu sering menjadi pengha lang bagi proses pembangunan bangsa Indonesia secara keseluruhan. Oleh sebab itu, nampaknya Orde Baru merasa perlu dan harus dihapuskan, dirombak dan/atau digant dengan yang baru. Makna pembangunan politik sebenarnya terletak di situ, yaitu merombak atau mengganti struktur yang lama dengan struktur baru yang diusahakan akan mengeras pula melalui waktu (Huda, 2018).

Karena arah dan kebijakan Politik Orde Baru yang unik, hal ini telah menarik perhatian kalangan akademisi untuk merekareka orientasi pembangunan politiknya. Banyak sebutan tentang corak politik era Orde Baru. Sistem otoritarian-birokratik di dunia ketiga ditandai oleh tiga ciri khas. Pertama, semua pimpinan politik Dunia Ketiga harus berhadapan dengan masalah kekacauan dalam negeri (Rochadi, Pramanti, \& Sulaiman, 2019; Sweeney, 2004). Menurut syaratnya, masyarakat di dunia ketiga menghadapi bencana yang berasal dari banyak konflik kelompok intern dan dari rangsangan luar seperti tekanan asing untuk melakukan modernisasi, dan dislokasi ekonomi internasional. Elite yang berkuasa, pengawasan birokratik sering merupakan cara terefisien untuk mengurangi "chaos" yang menggerogoti.

Kedua, dari perspektif ekonomi, rezim birokratik dapat menyediakan kerangka pemerintah yang menyatu yang 
memungkinkan elit yang berkuasa menjaga kekuatan ekonomi atau mungkin memperluas pertumbuhan ekonomi. Ketiga, selama abad terakhir badan-badan asing telah mempermudah dominasi sistem otoritarian-birokratik. Sistem politik Indonesia selama Orde Baru memang dalam banyak hal berusaha memenuhi tuntutan yang sesuai dengan ketiga ciri di atas.

Keberadaan tersebut, menurut hemat penulis tidak bisa dilepaskan dari kondisi internal bangsa Indonesia sendiri yang sangat heterogen. Kenyataan adanya hiteroginitas dalam budaya, bahasa, agama, geografi ini telah melahirkan sebuah masalah yang sangat pelik terutama menyangkut upaya membangun politik bangsa. Dengan kondisi yang heterogen inilah upaya Pembangunan Politik di Indonesia menjadi sangat menarik untuk diteliti terutama yang menyangkut masalah primoradialisme (Hidayat, 2019; Resminingayu, 2020; Rizqi, 2020).

\subsubsection{Masa Orde Reformasi}

Proses pergantian kekuasaan dari Orde Baru ke Orde Reformasi ditandai dengan adanya aksi mahasiswa yang menuntut perubahan politik. Akhirnya melalui aksi mahasiswa ini terjadi transfer kekuasaan dari Suharto Ke B.J. Habibie (Christian, 2017; Kristiono, 2017).

Hampir enam belas tahun setelah Reformasi digulirkan, perkembangan Demokrasi di Indonesia belum merasakan manfaat yang signifikan dari perbaikan kehidupan bangsa. Banyak orang mulai meragukan janji demokrasi di negeri ini. Dari penjelajahan hampir setiap minggu melalui Cakrawala Nusantara, dari kedekatan dengan bau keringat dan kaki nasional, dengan cepat menangkap celahcelah arsitektur negara kita. Setelah reformasi demokrasi digulirkan, tenunan Indonesia tercabik-cabik karena simpulsimpulnya yang rapuh (Supriyanto, 2021).

Lebih jauh, Indonesia telah menyaksikan kebangkitan aktivisme Islam yang menyerukan penerapan syariah dan pembentukan kekhalifahan. Salim dan Azra
(2003) berpendapat bahwa Islam politik setelah era Suharto dicirikan oleh apa yang dikenal sebagai "formalisasi Islam", terlihat dari meningkatnya tuntutan untuk penerapan hukum Islam dan menjamurnya ajaran Islam. Gerakan revivalis muncul seperti Hizbut Tahrir Indonesia (HTI), Front Pembela Islam (FPI), Majelis Mujahidin Indonesia (MMI), dan Forum Umat Islam (FUI) di berbagai daerah di tanah air (Munabari et, al. 2020; Umam, 2019a, 2019b). Sebelum runtuhnya Orde Baru, gerakan-gerakan ini beroperasi di bawah tanah untuk menghindari represi rezim.

Penggulingan rezim membuka ruang politik bagi gerakan-gerakan ini, memungkinkan mereka untuk secara konsisten mengkampanyekan penerapan syariah melalui aksi kolektif, seperti protes, mobilisasi massa, pernyataan di platform media, petisi, dan metode lainnya (Hilmy, 2015). Gerakan-gerakan ini telah membahas berbagai masalah, mulai dari masalah ekonomi seperti kenaikan harga bensin hingga pornografi, seperti yang tercermin dalam protes terhadap tuan rumah Miss World. Protes ini pada prinsipnya bertujuan untuk menyoroti ketidakmampuan pemerintah untuk mengatasi masalah yang ada sekaligus menawarkan syariah sebagai solusi mereka (Munabari et al., 2020). Sejak runtuhnya rezim Suharto pada 1998, Indonesia telah menyaksikan kebangkitan aktivisme Islam yang menyerukan penerapan syariah dan pembentukan kekhalifahan.

Berdasarkan pada temuan yang ada menunjukan bahwa politik identitas menjadi tantangan sendiri dalam membangun budaya nasional, Politik identitas di Indonesia telah berlangsung sejak era pembentukan negarabangsa hingga saat ini, hal ini sejalan dengan apa yang dikemukakan Hidayat (2019). Dengan demikian, pertarungan dan mobilisasi kekuatan politik berdasarkan latar belakang identitas bukanlah fenomena baru di Indonesia (Wahidin et al., 2020). Namun, harus diakui bahwa praktik politik identitas di Indonesia menemukan momentum yang eksplosif setelah Orde Reformasi. 
Diadopsinya sistem pemerintahan yang terdesentralisasi, pemekaran wilayah, sistem multi partai dan sistem pemilihan lokal, telah memicu kebangkitan politik identitas (Maemunah, 2020; Pamungkas \& Arifin, 2019; Wahidin et al., 2020). Sejak Era Reformasi, misalnya, dalam berbagai Pilkada di Indonesia, fenomena bentrokan simbol identitas telah muncul sebagai modal politik calon pemimpin daerah (Laporan LSI, 2008). Selanjutnya dampak maraknya praktik politik identitas di Indonesia Indonesia berbasis primordialisme ini adalah konflik antar kelompok yang memecah belah bangsa. Kondisi tersebut diperparah oleh realitas masyarakat post-truth Indonesia kontemporer, di mana fakta dan kebenaran dikalahkan oleh keyakinan dan emosi (Hidayat, 2019). Kondisi emosional masyarakat di era post-truth dituntun oleh merebaknya informasi di media sosial yang kurang bertanggung jawab, dengan menyebar hoaks, yang banyak beredar, terutama pada masa pemilu (Juditha, 2019).

\section{Kesimpulan}

Proses unifikasi bangsa merupakan hal yang sangat krusial dalam sebuah negara. Temuan menunjukan bahwa sumber ketidaksuksesan suatu bangsa dalam merajut perbedaan adalah adanya ikatan primordial yang kuat. Hal ini berimplikasi pada rendahnya rasa nasionalisme yang seharusnya terbentuk setelah negara memproklamirkan dirinya sebagai sebuah nation state. Dengan rendahnya nasionalisme sebuah bangsa, maka akan sangat rentan terjadinya terjadi gesekan antar bangsa sendiri, dan mudahnya ifiltrasi ideology dan budaya lain sehingga menggerus persatuan dan kesatuan bangsa. Indonesia yang ditakdirkan menjadi sebuah negara dengan tingkat heterogenitas yang tinggi mengalami problem serius dalam membangun budaya nasional.

Dari mulai Indonesia lahir, sampai sekarang selalu disibukan dengan pembangunan budaya nasional agar dapat meminimalisir terjadinya konflik baik konflik horizontal maupun vertikal. Bhineka
Tunggal Ika yang menjadi slogan kehidupan berbangsa dan bernegara tidak bisa berdiri sendiri tanpa adanya upaya untuk penegakan. Negara, dalam hal ini hadir dan berusaha agar ke-bhinekaan terikat kuat dalam ke-ikaan yang telah dilakukan mulai masa Orde Lama, Orde Baru, sampai sekarang. Dengan demikian, penguasa maupun warga negara Indonesia perlu menyadari bahwa keterikatan pada etnis, suku, bahasa, budaya, agama, dan daerah jangan sampai melampau keterikatan pada keindonesiaan.

Penelitian ini menggunakan pendekatan literature review, dengan demikian ada kelemahan data yang tidak bisa diungkapkan terutama kasus-kasus yang berbeda dan perlu penanganan yang berbeda pula. Berdasarkan hal tersebut, perlu ada penelitian ke depan terkait dengan resolusi konflik dari kasus kasus spesifik untuk dijadikan sebagai pedemonan penyelesasian kasus serupa di Indonesia. Lebih jauh, temuan penelitian ini berimplikasi pada pengembangan pendidikan di Indonesia. Pemerintah harus mengembangkan Misi pendidikan yang menyentuh aspek soft-skill berupa penguatan karakter kebangsaan.

\section{Daftar Pustaka}

Alkatiri, W. (2018). Reconsidering the modern nation state in the Anthropocene. Scripta Instituti Donneriani Aboensis, 28, 116-158. https://doi.org/10.30674/scripta.70070

Asmoro, N., Prihantoro, M., \& Fikri, I. (2021). Strengthening the Development of State Defense Resources and Building the National Logistic Reserves. 5(1), 54-59. https://doi.org/10.11648/j.stpp.202105 01.16

Baswedan, A. R. (2004). Sirkulasi Suara dalam Pemilu 2004. Analisis CSIS, 33(2), 173-189.

Berger, E. C. (2006). Permanent War on Peru'S Periphery: Frontier Identity and the Politics of Conflict in 17Th 
Century Chile.

Boangmanalu, A. S. (2009). Ampe Sahrianita Boangmanalu: Pandangan PKS Pakpak Bharat Terhadap Partisipasi Politik Perempuan, 2009.

Christian, H. A. and D. (2017). Perjalanan Reformasi Ekonomi Indonesia 19972016. (August), 1-16. Retrieved from https://www.csis.or.id/uploaded_file/p ublications/perjalanan_reformasi_ekon omi_indonesia_1997-2016.pdf

Darby, J., Li, C. W., \& Muscatelli, V. A. (2004). Political uncertainty, public expenditure and growth. European Journal of Political Economy, 20(1), 153-179.

https://doi.org/10.1016/j.ejpoleco.2003 .01 .001

Fawaid, A., Zamroni, \& Baharun, H. (2019). Contesting sacred architecture: Politics of "nation-state" in the battles of mosques in Java. Qudus International Journal of Islamic Studies, 7(1), 129171.

https://doi.org/10.21043/qijis.v7i1.436 5

Fionna, U. (2016). The trap of pop-charisma for the institutionalization of Indonesia's post-Suharto parties. Asian Journal of Political Science, 24(1), 124-141.

https://doi.org/10.1080/02185377.201 5.1136227

Gauthier, D. J. (2011). Martin Heidegger, Emmanuel Levinas, and the politics of dwelling. (December), 194.

Hadiz, V. R. (2017). Indonesia's year of democratic setbacks: towards a new phase of deepening illiberalism? Bulletin of Indonesian Economic Studies, 53(3), 261-278. https://doi.org/10.1080/00074918.201 7.1410311

Hidayat, M. A. (2019). Identity in the Contemporary Indonesian Post-Truth
Society - Primordialism on Social Media in the 2017 Election of the DKI Jakarta Governor. (ICoCSPA 2018), 42-46.

https://doi.org/10.5220/000881650042 0046

Hilmy, M. (2015). Radikalisme Agama Dan Politik Demokrasi Di Indonesia PascaOrde Baru. MIQOT: Jurnal Ilmu-Ilmu Keislaman, 39(2), 407-425. https://doi.org/10.30821/miqot.v39i2.3 3

Hooghe, L., \& Marks, G. (2017). Cleavage Theory Meets Europe's Crises : Lipset , Rokkan , and the Transnational Cleavage. Journal of European Public Policy, Special Is(April). https://doi.org/10.1080/13501763.201 7.1310279

Huda, M. C. (2018). Meneguhkan Pancasila Sebagai Ideologi Bernegara: Implemetasi Nilai-Nilai Keseimbangan dalam Upaya Pembangunan Hukum di Indonesia. Resolusi: Jurnal Sosial Politik, 1(1), 78-99. https://doi.org/https://doi.org/10.2489/ resolusi.v1i1.160

Juditha, C. (2019). Buzzer di Media Sosial Pada Pilkada dan Pemilu Indonesia Buzzer in Social Media in Local Elections and Indonesian Elections. Prosiding Seminar Nasional Komunikasi Dan Informatika, Vol. 3, pp. 199-212.

Kristiono, N. (2017). Penguatan Ideologi Pancasila Di Kalangan Mahasiswa Universitas Negeri Semarang. Harmony, 2(2), 193-204. Retrieved from

https://journal.unnes.ac.id/sju/index.ph p/harmony/article/view/20171/9563

Laporan LSI. (2008). Faktor Etnis dalam Pilkada. Lingkaran Surver Indonesia.

Leib, J., \& Garretson, P. (2003). the Florida State University College of Social Sciences Shifting Turkish American 
Identity Formations in the. World Trade.

Maemunah, M. (2020). Voting Results Concurrent Election in Indonesia in 2019. CIVICUS: PendidikanPenelitian-Pengabdian Pendidikan Pancasila Dan Kewarganegaraan, $8(2)$,

https://doi.org/10.31764/civicus.v8i2.2 860

Miedema, T. E. (2010). Violent Conflict and Social Capital in Ethnically-Polarized Developing Countries. A Thesis Submitted in Conformity with the Requirements for the Degree of Doctor of Juridical Science Graduate Department of the Faculty of Law University of Toronto (C).

Munabari, F., Larasati, N. U., Ihsan, R., \& Nurhadiyanto, L. (2020). Islamic Revivalism in Indonesia: The Caliphate, Sharia, NKRI, Democracy, and the Nation-State. Jurnal Politik, $5(2)$, 281. https://doi.org/10.7454/jp.v5i2.263

Musofiana, I., \& Maerani, I. A. (2020). JPH: Jurnal Pembaharuan Hukum Volume 7, Number 3, December 2020. 7(3Musofiana, Ida, and Ira Alia Maerani, 'JPH: Jurnal Pembaharuan Hukum Volume 7, Number 3, December 2020', 7.3 (2020), 201-10), 201-210.

Nurjaman, A., Suprapto, B., \& Masmuh, A. (2018). Nationalist Vs Islamic: The dynamic of politik aliran in postsuharto Indonesia. Pertanika Journal of Social Sciences and Humanities, 26(3), 2009-2020.

Pamungkas, A. D., \& Arifin, R. (2019). Demokrasi Dan Kampanye Hitam Dalam Penyelenggaraan Pemilu Di Indonesia. Jurnal Syariah Dan Hukum, 17(9), 16-30.

Partai, T., \& Demokrasi, B. (2012). Pemilu Alternatif ala Bung Hatta :
Partnership, K. (2008). Kebijakan Otonomi Khusus di Indonesia. Retrieved from www.kemitraan.or.id/.../Kebijakan Otonomi Khusus Di Indonesia.pdf

Reimondos, A., \& Mcdonald, P. (2015). International Journal of Indonesian Studies, Vol 1 2013. International Journal of Indonesian Studies, 1(2), 79-109.

Resminingayu, D. H. (2020). Revisiting Ethnicity in Southeast Asia. Paradigma: Jurnal Kajian Budaya, 10(3), 319. https://doi.org/10.17510/paradigma.v1 $0 \mathrm{i} 3.370$

Rizqi, A. R. (2020). Pancasila in the Primordialism and Modernism Intersections. 429(Icasseth 2019), 24 28.

https://doi.org/10.2991/assehr.k.20040 2.006

Rochadi, A. F. S., Pramanti, A., \& Sulaiman, A. (2019). Labour, democracy and identity politics, in Indonesian industry during the Jokowi Era. International Journal of Innovation, Creativity and Change, 10(7), 320-331.

Saddam, S., Mubin, I., \& SW, D. E. M. (2020). Perbandingan Sistem Sosial Budaya Indonesia Dari Masyarakat Majemuk Ke Masyarakat Multikultural. Historis: Jurnal Kajian, Penelitian Dan Pengembangan Pendidikan Sejarah, 5(2), 136-145.

Sai, D. K. (2008), the American Occupation of the Hawaiian Kingdom: Beginning the Transition From Occupied To Restored State.

Sobari, W. (2016). Anut Grubyuk in the Voting Process: The Neglected Explanation of Javanese Voters (Preliminary Findings). Southeast Asian Studies, 5(2), 239-268. https://doi.org/10.20495/seas.5.2

Supriyanto, E. E. (2021). Revitalization of 
Pancasila as a Solution to The Problems Faced by The Indonesian Nation. Jurnal Pendidikan Nusantara, 1(2), 52-61.

Sweeney, K. J. (2004). a Dyadic Theory of Conflict: Power and Interests in World Politics.

Tanzi, V. (1998). The Demise of the Nation State? IMF Working Papers, 98(120), 1. https://doi.org/10.5089/978145185424 4.001

Tradisi, D., An, P. A., Jamil, M., \& Kunci, K. (n.d.). Pergeseran epistemologi dalam tradisi penafsiran al-qur'an.

Trihartono, A., \& Patriadi, H. B. (2016). The 2014 Indonesian general election and beyond: Melting "frozen" cleavages. Asian Journal of Comparative Politics, 1(1), 25-43. https://doi.org/10.1177/205789111562 0699

Ufen, A. (2006). Political Parties in PostSuharto Indonesia: Between Politik Aliran and "Philippinisation." German Institute of Global and Area Studies, Working $P a$ (December), 1-35. Retrieved from http://papers.ssrn.com/sol3/papers.cfm ?abstract_id=2123232

Ufen, A. (2008). The Evolution of Cleavages in the Indonesian Party System. GIGA Working Papers, April(74), 5-24. Retrieved from www.giga-hamburg.de/workingpapers

Umam, F. (2019a). Ideological Involution of the Islamists. ULUL ALBAB Jurnal Studi Islam, 20(1), 25. https://doi.org/10.18860/ua.v20i1.5714

Umam, F. (2019b). Ideological Involution of the Islamists. ULUL ALBAB Jurnal Studi Islam, 20(1), 25-45. https://doi.org/10.18860/ua.v20i1.5714

Wahidin, D. T. S., Muhyidin, A., Iswahyuni, I., \& Ilmar, A. (2020). Partai Politik dan Perilaku Pemilih Di Indonesia (Studi Pada Pemilu Legislatif 2009, 2014, dan 2019). Journal of Government and Civil Society, 4(1), 131. https://doi.org/10.31000/jgcs.v4i1.237 6

Weiss, M. L. (2010). Southeast Asia' s Muslim Majority Democracies Elections and Islamism outside the MENA Region. Taiwan Journal of Democracy, 6(1), 81-106.

Xiao, Y., \& Watson, M. (2019). Guidance on Conducting a Systematic Literature Review. Journal of Planning Education and Research, 39(1), 93112. https://doi.org/10.1177/0739456X1772 3971 